\title{
409 多波長蛍光の同時検出による高効率 DNA チップ検出菨置の開発 \\ Simultaneous detection of multi-line fluorescence for DNA micro array scanner
}

\author{
○学 Munkhbayar Nurzed（茨城大大学院） 林 照剛（茨城大） \\ 正 前川 克廣（茨城大） 永野伸一（茨城大学大学院)
}

Munkhbayar Nurzed, Hayashi Tertake, Maekawa Katsuhiro, Nagano Shinichi

Ibaraki University, 4-12-1 Nakanarusawa, Hitachi 316-8511

\begin{abstract}
The present paper suggests a new method for high speed and precise detection of fluorescent signals. Only one detecting device is needed for detecting multi-color signals. Different frequency is attached each signals. We can simultaneously distinguish each fluorescent signal by using frequency analysis. This paper describe about a feasibility of this method.
\end{abstract}

Key words: flow cytometry, fluorescent,

\section{1. はじめに}

近年, 複数種の細胞や DNA を異なる蛍光を発する蛍光 色素でそれぞれラベリングし，マルチカラー緟光解析を行 う蛍光色素多重染色法が実用化され, 複数パラメータの計 測に利用されている ${ }^{1)}$ ．この技術は，細胞の分類や DNA 発現解析等に有効であるが，蛍光測定サンプル数が非常に 多く，測定に長時間を要することから，測定速度の向上が 強く求められている.

本研究では，マルチカラー蛍光信号を周波数空間で測定 することにより，SN 比の向上を実現し，さらにそれぞれ の蛍光信号を一台の検出装置で同時検出する方法を提案し ている. 本手法により, 蛍光測定精度の向上とマルチパラ メー夕計測時の測定時間の短縮が見込まれる.

本報では本手法の妥当性を検証するため, 基礎的なシミ ユレーションおよび実験を行うた結果について報告する.

\section{2. 蛍光信号の周波数空間検出原理}

蛍光物質の濃度と蛍光強度の間には物質の濃度が小さい範 囲では, 近似的に比例関係式が成り立つことが知られている。 この場合, 蛍光強度 $\mathrm{F}$ は, 入射光強度を $\mathrm{I}_{0}$, モル吸光係数を $\varepsilon$, 物質の濃度を $\mathrm{c}$, 光路長を $\mathrm{d}$ とすると次式で与えられる ${ }^{2)}$.

$$
F=I_{0} \phi \times 2.303 \varepsilon c d
$$

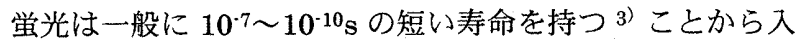
射光 $\mathrm{I}_{0}$ に強度変調を加え周期性を与えれば，式（1）より発 生する蛍光 $\mathrm{F}$ も入射光の周期に対応した周期性を示す.

この周期性を持つ蛍光信号を同時に検出し，周波数解析を 行えば, 蛍光信号の周波数スペクトルが得られる.

例えば Cy3, Cy5 という 2 種類の蛍光色素を励起する場合, 励起波長としてそれぞれ $543 \mathrm{~nm}$ ，と633nm の 2 つの光源が 使用される．各光源にそれぞれ $\omega_{1}, \omega_{2}$ の周期で強度変調を 加えれば，各色素が励起され得られる蛍光信号は $\omega_{1}{ }^{\prime}, \omega_{2}$ ’ となる.したがって, 蛍光強度 $\mathrm{F}$ の時間関数 $\mathrm{F}(\mathrm{t})$ をフーリエ 変換すれば, 周期 $\omega_{1}, \omega_{2}$ 'の位置にスペクトルが確認でき ることから，一台の検出装置で 2 色励起蛍光を同時に独立し て検出できる.

\section{3. 本研究の特徽}

従来手法では，マルチカラー蛍光検出を実現するために， 各色の蛍光をそれぞれ測定する，もしくは，複数の受光装置
と波長選択フィルターにより各巣光を同時に測定するという 方法がとられていた. しかし, 前者は測定時間の長さが, 後 者は測定装置の複雑さが問題とされていた.

本手法では, 2 種類以上の蛍光信号についても, 周波数解 析によって，各信号成分を独立して検出できる．これは，1 回の測定で, しかも単一の受光装置で, 複数の蛍光信号を同 時検出できることを意味しており, 装置の簡略化と測定の高 速化を両立させることができる.

\section{4. 周波数空間検出シミュレーション}

Fig1 (a)，(b)，(c)に，周期 $\omega_{1} ， \omega_{2}, \omega_{3}$ の 3 つの周期を 持つ信号を合成した信号とそれぞれの周波数解析結果を
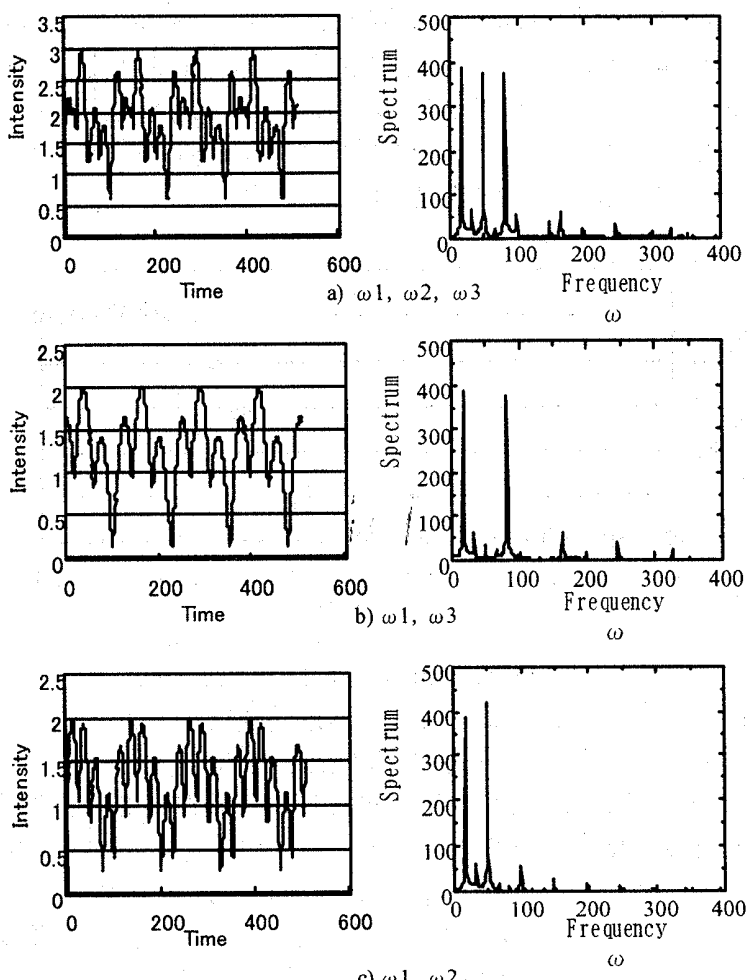

c) $\omega 1, \omega 2$

Fig.1 Fourier analysis of multi-frequency signals 
示す. 合成信号のフーリエ変換後の周波数スペクトルを観 察すると各周波数に対応したピークが独立して検出できる ことから，合成信号を単一装置で検出した場合でも，各周 波数成分の独立検出が実現できることが確認できる.

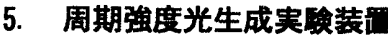

周波数信号検出を実現するため，液晶を用いて蛍光励起 光に強度変調を与え, 周期強度光を生成する実験を行った. 実験装置の概要をFig. 2.に示す.

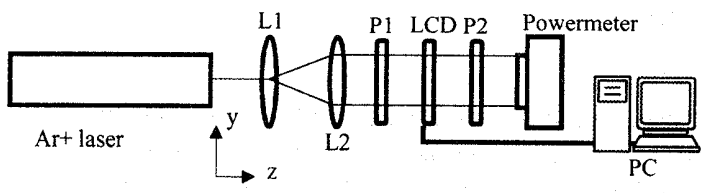

Fig.2 Schematic of frequency signal detection 波長 488nmのArイオンレーザ(Coherent Inc. Inova304C) のビーム径は，レンズL1 および L2 からなるコリメー夕光 学系により $1.5 \mathrm{~mm}$ から $5.0 \mathrm{~mm}$ へと拡大される. 拡大された 入射光の強度は, 偏光子 $\mathrm{P} 1, \mathrm{P} 2$ ，および液晶素子 LCD からな る可変強度変調マスクにより制御することができる，マス ク透過率の制御は，LCD に接続する PC 上から行い，透過光 の強度を Powermeter(ネオアーク（株）PM-371)によって 測定する。

使用した液晶素子の解像度は $800 \times 600$ pixel，画素サイ ズは一辺 $33 \mu \mathrm{m}$ である. 光線の進行方向が 乙 軸となるよう に, 座標軸を設定し, 偏光子 P1 の吸収軸を $\mathrm{x}$ 軸方向に設定 し，y 方向に偏光した光を透過させる，偏光子 P2 の吸収軸 は, P1 と直交するように y 軸方向に設定し, 液晶素子によ る可変強度変調マスクを構成している.

\section{6. 液晶素子の電気光学効果測定結果}

Fig. 2 の光学系において, 制御 PC から, 0 255 までの異 なる階調を液晶上に出力し, 光透過率の変化を測定した結 果をFig. 3 に示す.階調值は黒の出力が0で遮光を意味し， 白の出力が 255 で光透過を意味する. 0 から 255 までは, その数値に応じて光の透過量が増大する.

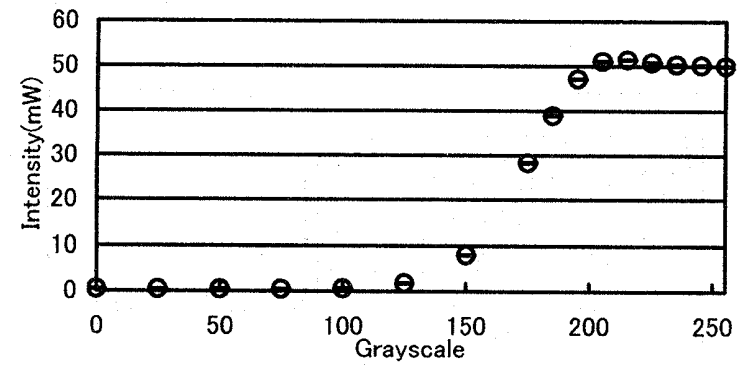

Fig. 3 Electro-optical effect of LCD panel

Fig. 3 から, 階調 250 付近で透過光強度が最大となり, 液晶素子の入射光強度透過率は最大で $70 \%$ 弱となること がわかる.また，階調 100〜200の間で，階調値に応じた透 過光強度の増大が見られることから，白から黒までの中間 調表示により, 光透過量を制御し周期強度光を生成できる. そこで，100〜200の階調を利用して，1階調の表示時間変 化させて，4つの周期の信号を作製した.Fig. 3 に作製し た 4 つの周期信号を液晶に出力し, 入射光強度を測定した 結果を示す．それぞれ，各階調の表示時間は, $200 \mathrm{~ms}, 150 \mathrm{ms,}$ 100ms, 50ms としている.Fig. 3 からわかるように液晶に同 一階調を表示する時間を短縮することで，その周期を制御

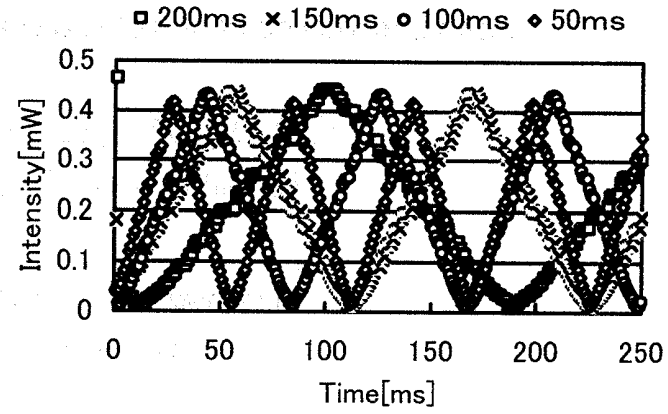

Fig.3 Multi-frequency signals for incident light することができる.Fig. 4 に上記 4 信号の合成結果を示す. さらに Fig. 5 に合成信号のフーリ工解析による周波数スペ クトルを示す.Fig. 5 の結果から，時間空間でその識別が 困難な周期的信号を周波数空間で容易に, 識別できること がわかる．したがって，入射光強度に対応した蛍光信号を 周波数空間で検出できれば，複数信号を同時検出しても， 各信号を独立して検出することが可能となる.

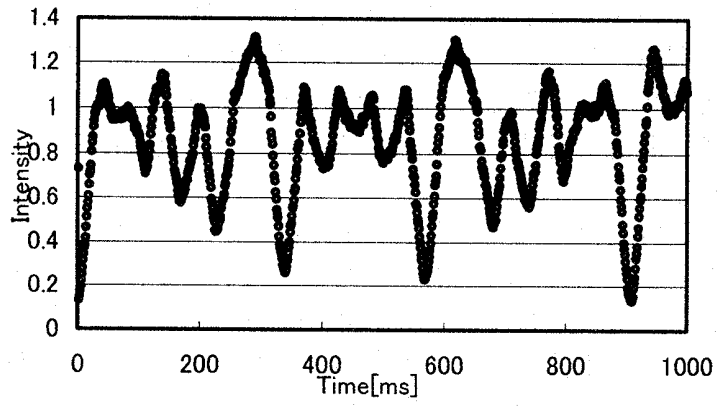

Fig.4 Synthesis of four frequency signals

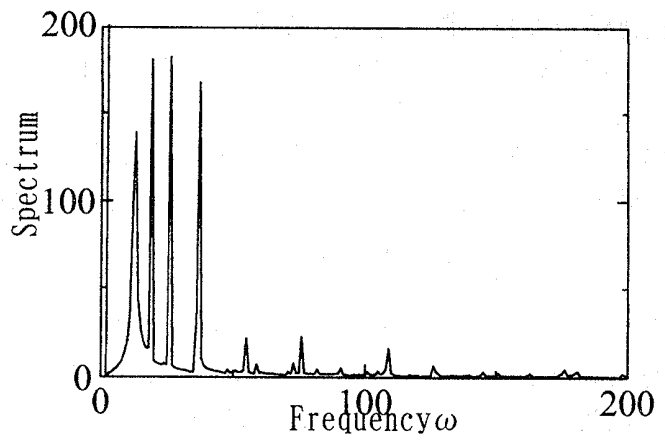

Fig. 5 Fourier transformation of synthesis signal

\section{7. おわりに}

液晶マスクを利用して周期的入射光を作製し，4つの異 なる周期的信号からなる合成信号を作製した，さらに，高 速フーリエ変換によって，この信号の周波数スペクトルを 観察し, 各信号成分に対応したスペクトルが周波数空間で 独立して観察できることを確認した.

今後は，作製した信号により蛍光を励起し，蛍光信号の 周波数独立識別の妥当性を検証する.

\section{参考文献}

1）天神美夫，忘用サイトメトリ一，医学書院，2000，p353

2) 猪飼篤, 生物学基礎コース 分析・計測法, 丸善, 1998, p57

3）速解光サイエンス辞典，オプトロニクス社, 1998, p205 